\title{
Crop Management System Based on Digital Technologies
}

\author{
A.R. Zakirova ${ }^{1 *}$, G.S. Klychova ${ }^{1}$, A.R. Yusupova ${ }^{1}, I . G$. Nikitenko $^{2}$ and A.M. Zakirov ${ }^{2}$ \\ ${ }^{1}$ Kazan State Agrarian University, Kazan, 420015, Russia \\ ${ }^{2}$ Kazan (Volga region) Federal University, Kazan, 420008, Russia
}

\begin{abstract}
Crop farming is one of the most important branches of agriculture that ensures the food security of the country. For crop farming development, it is necessary to solve the problems of reducing the quantity and quality of the resulting crop due to insufficient nutrition and care, untimely harvesting and improper storage. To increase the efficiency and sustainability of the industry, it is necessary to digitalize both the production systems and decision-making processes at all levels of management. The study considers the stages of a digital crop management system: accounting for acreage with an electronic field map; organization of crop rotation taking into account organizational, soil-climatic and economic aspects of production; monitoring of technological operations; control of agricultural machinery with the formation of primary documents for accounting for completed works; maintaining a subsystem of material resources using the technic of precision farming; filling in technological maps and accounting for actually completed works with a list of works, the composition of agricultural aggregates, the timing of operations, production rates and fuel consumption, the need for seeds, fertilizers, plant protection products, and the cost of resources. The increased attention to the problem of digital agriculture on the part of the state and the highly competitive environment promote the use of new technological mechanisms and methods of work by agricultural producers, which are based on the use of Internet technologies, satellite navigation, robotics, sensors and sensors, and unmanned vehicles. Digitalization of agricultural processes allows increasing crop productivity, the efficiency of using material resources, equipment and human potential.
\end{abstract}

\section{Introduction}

Currently, agriculture is significantly behind other sectors of Russian economics in the use of innovative tools. Due to its conservatism, the agro-industrial sector is the least digitalized industry not only in the Russian Federation but also around the world. But, as experts admit, in the next decade, the digital transformation of the agricultural industry is inevitable. This is due to the fact that with a deficit of land resources, the growing demand for food supply, due to the increase in the population, can only be covered by the introduction of digital technologies.

Among the main trends in the development of digital technologies for agriculture, it should be noted the management systems of agricultural enterprises in terms of monitoring fieldwork by synchronizing with built-in means of interaction with the external environment (sensors, weather stations, etc.). Ready-made systems should collect and analyse information, optimize the production process, and offer recommendations for improving production efficiency and reducing losses due to the irrational use of agricultural machinery, labour, and inventory [1]. Digital crop management systems should include mandatory elements related to accounting for acreage, crop rotation, operation of the agricultural machinery fleet, taking into account the availability and use of seeds, fertilizers, plant protection products, and monitoring the performance of operations under the technological maps.

\section{Methods}

The study uses economic methods: grouping, systematization, classification, as well as generalization of special scientific literature based on the studied problem. As a result, the sequence of organization of the crop management system is systematized. Analysing the problem, the state of the crop production industry was characterized. The digital material is grouped and presented in analytical tables using the graphical method.

\section{Results}

The basis of the country's food security, which provides a significant share of the products consumed by the population, is one of the most important branches of agriculture - crop farming. The crop industry has a number of features and focuses on obtaining certain products [2]. Modern crop farming includes the cultivation of various types of crops, in connection with which, it is customary to distinguish the following areas: grain production, horticulture and viticulture, fruit crop cultivation, vegetable and melon growing, potato growing, technical crop production, feed production.

* Corresponding author: zakirovaar@mail.ru 
The area of crops in the Russian Federation (as of January 1, 2020) occupies 79,948 thousand ha. Among the subjects of the Russian Federation in the first place in terms of acreage is the Altai Krai - 5,146.91 thousand ha (Table 1). The Republic of Tatarstan is among the top ten subjects with an area of 2,947.08 thousand ha of crops. The territory designated for the crop industry occupies $44 \%$ of the land of Tatarstan.

Table 1. Acreage of crops in respect of the states of the Russian Federation in 2019

\begin{tabular}{|c|c|c|}
\hline No. & States of the Russian Federation & Area, thousand ha \\
\hline 1 & Altai Krai & 5146,91 \\
\hline 2 & Rostov Region & $4,695.04$ \\
\hline 3 & Orenburg Region & 4273,65 \\
\hline 4 & Saratov Region & $4,061.02$ \\
\hline 5 & Krasnodar Region & $3,708.52$ \\
\hline 6 & Stavropol Krai & $3,156.58$ \\
\hline 7 & Volgograd Region & $3,146.12$ \\
\hline 8 & Republic of Tatarstan & $2,947.08$ \\
\hline 9 & Republic of Bashkortostan & $2,873.9$ \\
\hline 10 & Omsk Region & $2,864.13$ \\
\hline 11 & Voronezh Region & $2,638.51$ \\
\hline 12 & Novosibirsk Region & $2,225.7$ \\
\hline 13 & Samara Region & $2,113.55$ \\
\hline 14 & Chelyabinsk Region & $1,949.82$ \\
\hline 15 & Tambov Region & $1,789.7$ \\
\hline
\end{tabular}

Source: https://fedstat.ru/indicator/31328

The agro-industrial complex of the Republic of Tatarstan provides the population with basic food products for its production. The agro-climatic conditions of the republic are moderately favourable for crop farming. But for cultivating water-intensive crops, Tatarstan is supposed to belong to the zone of risky agriculture [3]. Nevertheless, measures are being taken in the republic to introduce a water-saving set of actions. In the structure of agricultural land, $76 \%$ is occupied by arable land, $23 \%$ - pastures and hayfields (Fig. 1).

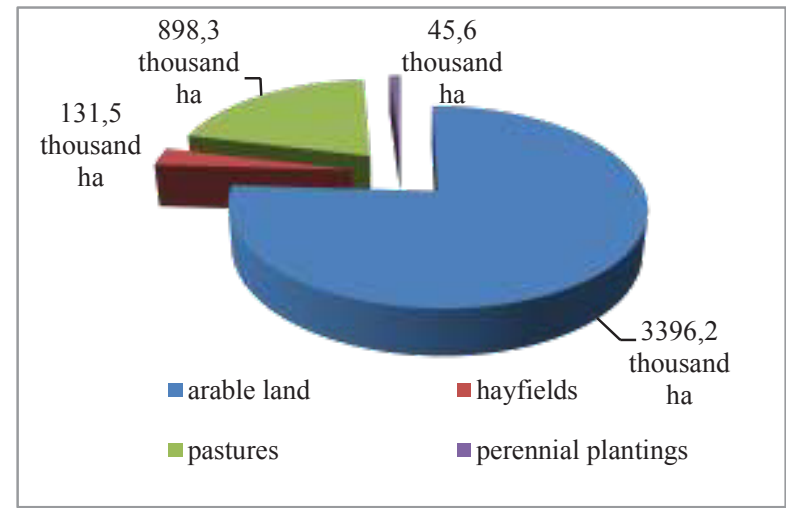

Fig. 1. Structure of agricultural land in the Republic of Tatarstan as of January 1, 2020. Source: https://tatstat.gks.ru/agriculture

The volume of agricultural production in actual prices tends to grow: by 2019 , it increased by $17 \%$ compared to 2015 and amounted to 248,781 million rubles. (fig. 2). The decrease in the cost of gross output in 2018 by $4 \%$ compared to the previous year was caused by unfavourable climatic conditions, so, during the growing season, about 20 municipal districts of the republic were subjected to soil and atmospheric drought.

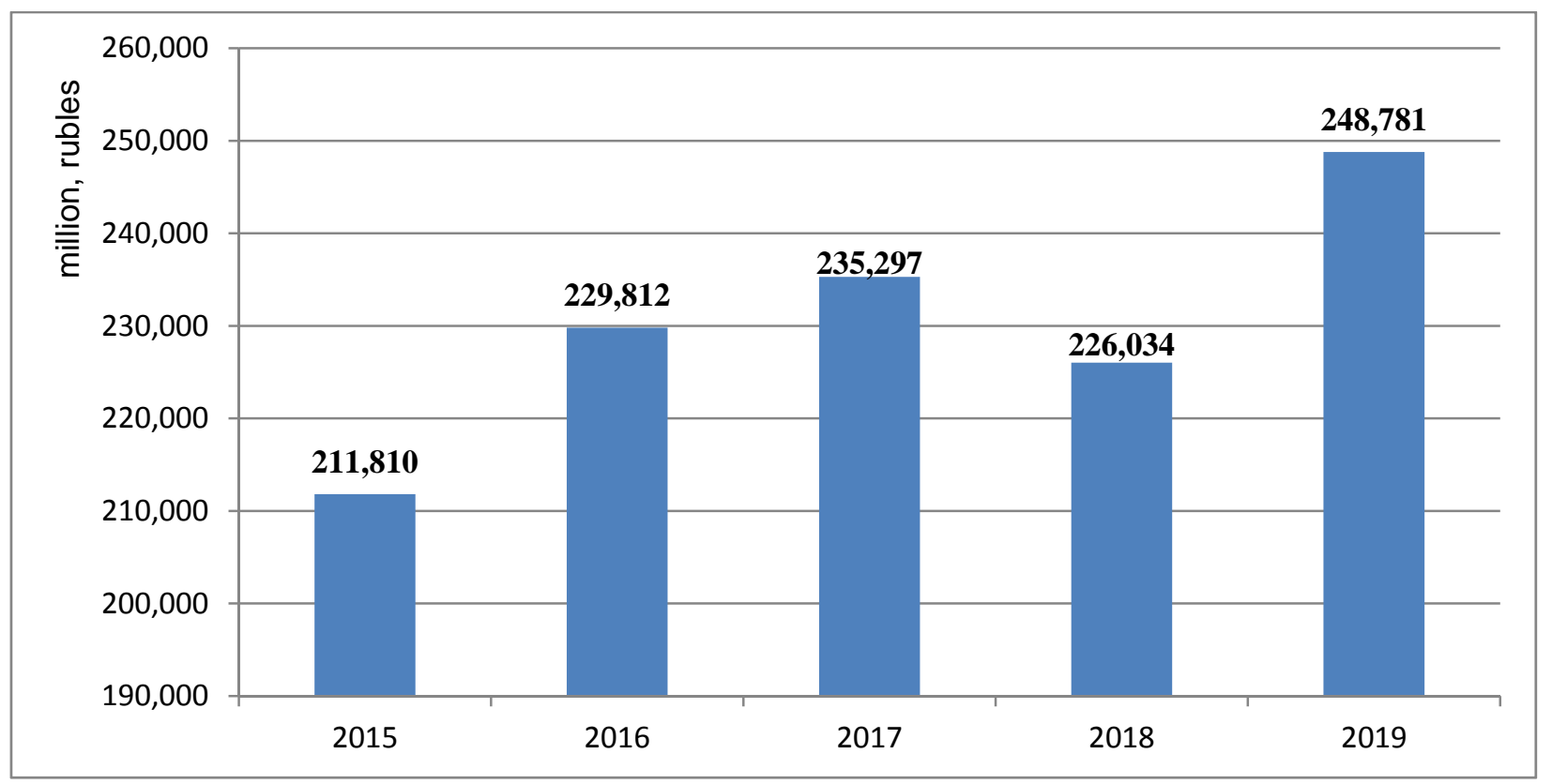

Fig. 2. Agricultural products in the Republic of Tatarstan. Source: https://tatstat.gks.ru/agriculture

Crop farming production was prepared in 2019 by 24,249 million rubles, which accounted for $50 \%$ of the cost of all agricultural products (Fig. 3). The increase in production is primarily due to an increase in productivity with a decrease in harvested areas. 


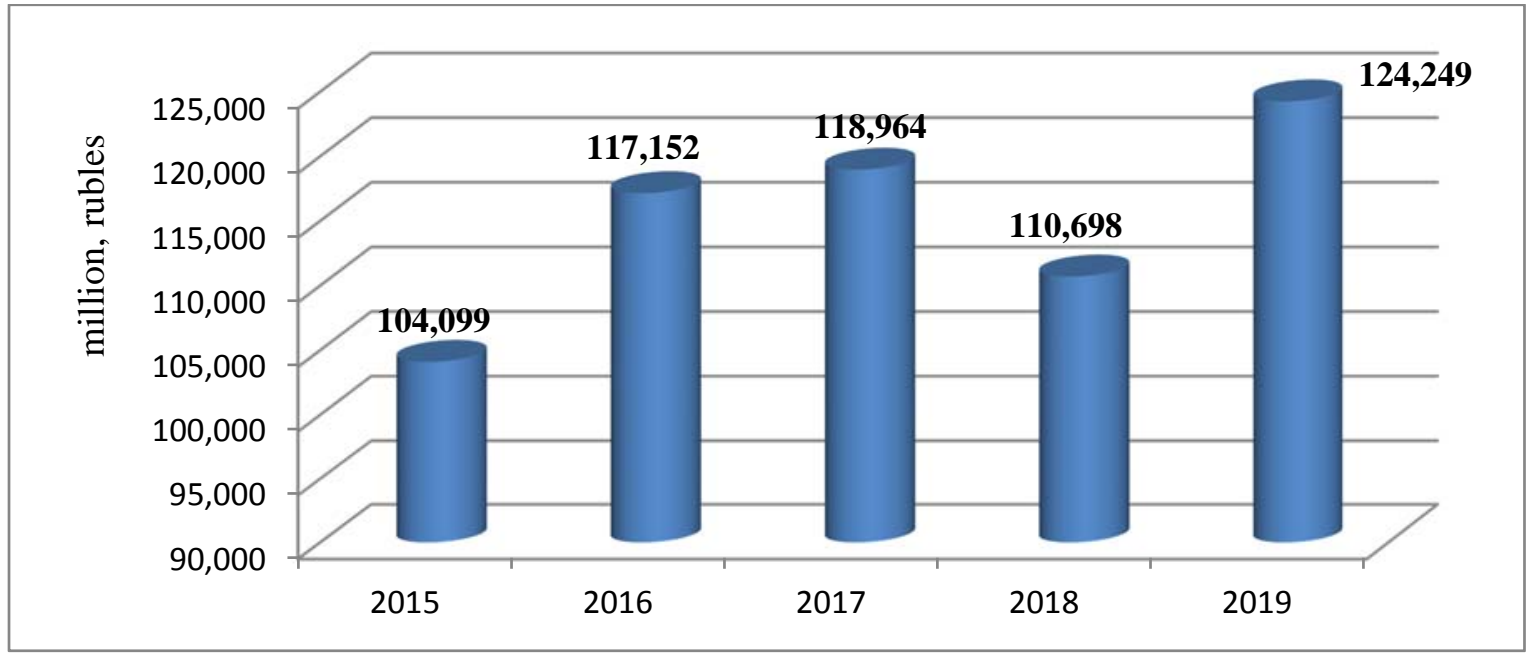

Fig. 3. Crop farming production in the Republic of Tatarstan. Source: https://tatstat.gks.ru/agriculture

For the developing the crop industry, it is necessary to solve the problems that arise in the production process in an unfavourable climate, poor quality of the land, competition, unstable financial situation, lack of equipment and machinery. A significant problem is not only a decrease in the quantity and quality of the resulting crop due to insufficient nutrition or care but also crop losses due to untimely harvesting and improper storage [4]. The creation of an effective digital process management system in crop production will solve the problems and stimulate the development of this branch of agriculture [5]. In this regard, it is proposed to develop a digital system of crop production, which is a set of certain stages of work based on geoinformation technologies (Fig. 4).

The first stage of digitalization is the accounting of acreage. The system should include an electronic map of farm fields with information on the level of groundwater, microclimate, and humus content in the soil. The fields can be added to the maps manually and with the help of technical tools. When the fields are added manually, the borders of each field are drawn on satellite images. A more technological way is to upload the field map into the KML format (from English Keyhole Markup Language - an XML-based markup language for representing three-dimensional geospatial data). Drones with a multispectral camera are used to develop the map. After that, the drones are used to collect operational information about the state of crops and identify problem areas that require additional examination. The sizes of the field are measured by going around the field with a satellite receiver (GPS, GLONASS) [6].

The electronic agricultural database contains the following information about the field: its area, type and level of soil quality, location, cadastral number. This database allows keeping records in the field book. The field book contains information about the actual costs and the products received from each field over several production cycles. Thus, the information base of longterm observations is formed, which is necessary to achieve a high level of production using a scientific approach. This contributes to making more informed management decisions. Turning to the data of the previous production cycles allows the farmers to avoid the overspending of material and financial resources.

The main source of reproduction of raw materials and food in agriculture is the land [7]. To reduce the level of various types of losses and to increase profitability, it is necessary to ensure rational land use, which implies maintaining the terms of planting crops and the structure of sown areas. The structure of acreage is the ratio of crops of different types of agricultural crops, expressed as a percentage of the total area of arable land. The structure of sown areas is formed taking into account the specialization of the agricultural enterprise, to increase soil quality and increase crop yields [8].

One of the most important indicators of agricultural production is the yield, which depends on many factors: climate, variety, cultivation technology, crop rotation. The determining factor is the proper crop rotation, that is, the scientifically-based alternation of crops. The system of crop rotation assigned to certain divisions serves as the basis of the organizational structure of agro-industrial enterprises. When developing a crop rotation system, it is necessary to conduct a thorough study of the characteristics of each crop: it is necessary to avoid using several varieties of the same crop (to prevent mixing of their qualities). As a result of the use of culture-appropriate precursors, a reduction in the degree of infection with fungal and bacterial diseases and pest damage is achieved. In addition, there is no accumulation of harmful microorganisms and insect larvae in the soil and no leaching of trace elements [9].

The digital system of crop production must necessarily reflect information about the structure of crop rotation: seasons, fields, cultivar (variety), dates of sowing and harvesting, the planned harvest. Control of crop rotation compliance is one of the tasks of the digital system, the solution of which is based on the organizational, soil-climatic and economic aspects of production management. Ultimately, crop rotation determines most of the other systems: the application of seeds, fertilizers and plant protection products, irrigation, protection against erosion, the use of agricultural machinery, the organization of the labour process [10]. 


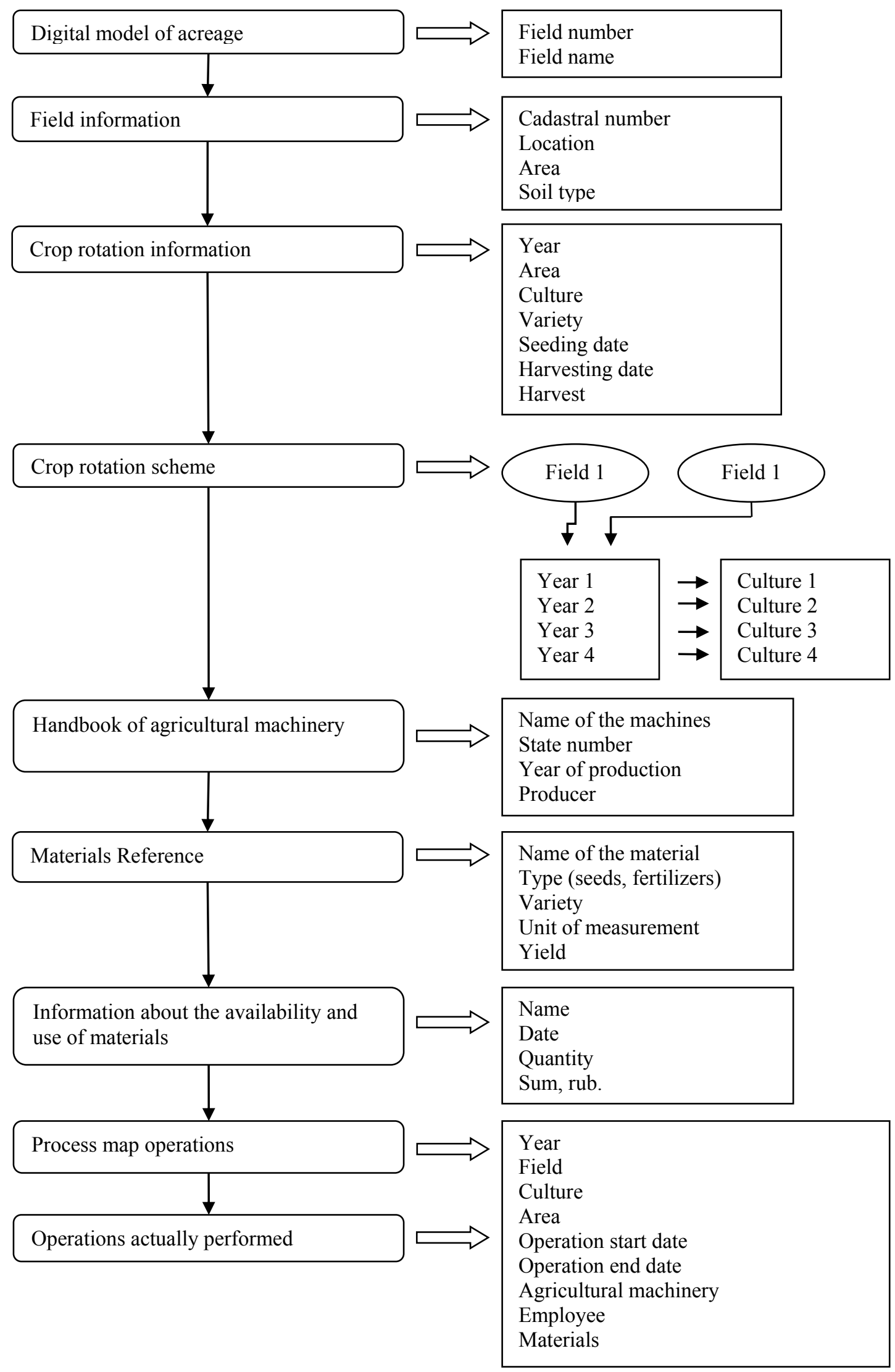

Fig. 4. Stages of the digital crop management system 
The most important element of the digital system of crop production is monitoring, that is, the supervision of technological operations to determine the need to adjust agricultural parameters. With the help of geoinformation systems, information is collected to analyse the effectiveness of the elements of the farming system. At the current stage of development, some processes can be monitored using devices installed on the units and automatically transmitted to the enterprise server, the rest is taken into account by specialists through visual observations of the state of the soil and plants. To determine the location of the equipment, the time of its operation, as well as the operations performed for fuel filling and its consumption, special programs are used to perform full monitoring of vehicles [11].

The basis of the digital system is a terminal installed on the agricultural machine, which receives signals from satellites and determines the coordinates of the location of the unit, while collecting data from sensors (fertilizer application, fuel using, seed sowing) and, together with the coordinates, transmits data to the enterprise server via Internet technologies. The user, in real-time, gets access to information and observes the movement of equipment, making reports, if necessary [12]. The use of the system contributes to a significant reduction in fuel consumption and the revision of the routes of vehicles, which provides higher productivity. Also, the possibility of unfair actions on the part of the staff is completely excluded.

The agricultural machinery subsystem includes:

1) making the schedules for the machinery use and its repair;

2) determination of the most acceptable routes of the displacing equipment from the garage to the field and from the field to the receiver point of finished products;

3 ) control over the equipment when performing field works [13];

4) making the primary documents on accounting for the performed works (route sheets, registration sheets of tractor drivers).

The information base for monitoring equipment serves as the basis for the development of standards for the production and consumption of fuel for agricultural machines in the field [14]. Analysis of satellite monitoring data can significantly improve the accuracy of standards and ensure more efficient work of specialists.

Agricultural aggregates are selected from the reference book "Agricultural machinery", which contains the characteristics of machines and equipment (name of machines, state number, year of manufacture, manufacturer). Based on the reference book, digital technologies are designed, and technological maps are developed.

The next element of the digital crop production system is the subsystem of material resources. The main accounting tool is precision agriculture, the essence of which is the most efficient use of seeds, fertilizers, plant protection products and fuel [15]. As a result, there is a reduction in production costs and an increase in productivity [16].
The subsystem of material resources should provide the following functions:

1) agrochemical survey of fields by robots;

2) development of maps of vegetation indices and distribution of chemical elements with an indication of the recommended dosage based on the data obtained on the state of land and crops;

3) differentiated application of fertilizers and plant protection products;

4) uniform spraying of the crop with special fertilizers using drones.

The basis for the digitalization of the crop production system is the filling of technological maps, which reflect the list of works, the composition of agricultural aggregates, the timing of operations, the production and consumption rates of fuel, the need for seeds, fertilizers, plant protection products, and the cost of resources. Since the part of the work is constant (soil treatment, harrowing, transportation of seeds, fertilizers, finished products, spraying of crops with pesticides, mowing and threshing of crops), it is advisable to develop an information base of standard technological maps. It will be enough to edit the template in accordance with the production conditions in a certain field. The norms of seeding, fertilization and consumption of plant protection products are included into the system's reference books.

Accounting for the works actually completed is also carried out using geoinformation technologies [17]. The electronic scales provide information about the volume of materials consumed; the intake of products from the field and the sale of products from the storage facilities are recorded. The data collected during monitoring is used to make various analytical reports in specialized software that processes the collected information. After that, based on the results of the software, the specialists must make decisions on the further development of the production process in a particular field [18].

\section{Conclusion}

Thus, in the course of the conducted research, it was established that the crop management system based on digital technologies is a set of stages based on the use of scientific knowledge about agricultural production and the use of modern technical means of monitoring and analysing data obtained from sensors and other devices. Registration of actual data in the system can be carried out both by direct entry of documents by the operator, and in a more technological way - by registering the operation through a mobile application for smartphones [19]. Thus, the specialist, being directly on the field, has access to up-to-date information, and can also register the fact of the operation. The registered data is uploaded to the information database when the connection is available.

Due to the correct selection of cost-effective units for performing operations, reducing labour costs and material and monetary costs per unit of production, the use of a digital system significantly improves the 
organization of the enterprise's activities. The introduction of digital technologies makes it possible to increase the efficiency of agricultural production and strengthen the position of the Russian Federation in the global agricultural market.

\section{References}

1. Ad.U. Mentsiev, Al.U. Mentsiev, E.F. Amirova, IOP Conf. Ser. Earth and Envir. Sci., III Int. Sci. Conf. (AGRITECH-III-2020) Agribusin., Envir. Engin. and Biotechnol., 32035 (2020), DOI: $10.1088 / 1755-1315 / 548 / 3 / 032035$

2. O.V. Kirillova, E.F. Amirova, M.G. Kuznetsov, G.A. Valeeva, G.P. Zakharova, BIO Web of Conf., 17, 00068

(2020), DOI: $10.1051 /$ bioconf $/ 20201700068$

3. R.A. Osipova, M.Yu. Gilyazov, S.Zh. Kuzhamberdieva, B.B. Abzhalelov, BIO Web of Conferences, 27, 00046 (2020), DOI: https://doi.org/10.1051/bioconf/20202700046

4. Sh.M. Gazetdinov, M.Kh. Gazetdinov, O.S. Semicheva, F.F. Gatina, BIO Web of Conf., 17, 00026 (2020), DOI: 10.1051/bioconf/20201700026

5. E. Amirova, M. Kuznetsov, E. Khakimova, A. Tolmacheva, BIO Web of Conferences, 27, 00055 (2020), DOI: https://doi.org/10.1051/bioconf/ 20202700055

6. O.V. Bakhareva et al., Infrastructure in the Region: Long-Term Investments of Institutional Investors in Russia, J. of Advan. Res. in Law and Econ., 6(3), 488-503 (2015)

7. R.A. Alborov, S.M. Kontsevaya, S.V. Kozmenkova, Digest Finance, 24(3(251)), 320-328 (2019), DOI: $10.24891 /$ df.24.3.320

8. Dz. Faizrakhmanov, A. Zakirova, G. Klychova, A. Yusupova, A. Klychova, E3S Web of Conf., 91, 06004 (2019), DOI: org/10.1051/e3sconf/ 20199106004

9. E.Yu. Ermakova, Yu.F. Korotkov, M.G. Kuznetsov, N.A. Nikolaev, Cleaning contaminated water by gravity flotation, Chem. and Petrol. Engin., 46(1-2), 40

10. M.S. Faskhutdinova, E.F. Amirova, I.N. Safiullin, L.G. Ibragimov, BIO Web of Conferences, 27, 00020 (2020), DOI: https://doi.org/10.1051/ bioconf/20202700020

11. N.F. Kashapov, M.M. Nafikov, M.Kh. Gazetdinov, M.M. Nafikova, A.R. Nigmatzyanov, IOP Conf. Ser. Mat. Sci. and Engin., 240, 012033 (2017), DOI: 10.1088/1757-899X/240/1/012033

12. F. Safiollin, G. Minnullin, S. Suleymanov, N. Loginov, D. Trautz, BIO Web of Conferences, 27, 00012 (2020), DOI: https://doi.org/10.1051/ bioconf/20202700012

13. E. Nurullin, R. Ibyatov, A. Dmitriev, D. Khaliullin, BIO Web of Conferences, 27, 00077 (2020), DOI: https://doi.org/10.1051/bioconf/20202700077

14. E.F. Amirova, O.V. Kirillova, M.G. Kuznetsov, Sh.M. Gazetdinov, BIO Web of Conf., 17, 00050 (2020), DOI: 10.1051/bioconf/20201700050

15. M. Amirov, I. Serzhanov, F. Shaikhutdinov, A. Serzhanova, K. Partoev, BIO Web of Conferences, 27, $00075 \quad$ (2020), DOI: https://doi.org/10.1051/bioconf/20202700075

16. G. Saidasheva, A. Kulikova, S. Nikitin, A. Lashchenkov, BIO Web of Conferences, 27, 00041 (2020), DOI: https://doi.org/10.1051/bioconf/ 2020270004

17. D.A. Mustashkina, N.V. Karpova, A.S. Makarov, M.M. Khannanov, BIO Web of Conferences, 27, 00042 (2020), DOI: https://doi.org/10.1051/ bioconf/20202700042

18. A. Zakirova, G. Klychova, I. Gimadiev, A. Yusupova, V. Kirillova, E3S Web of Conf. 2018 Top. Probl. of Architect., Civil Engin. and Envir. Econ. (TPACEE 2018), $06003 \quad$ (2019), DOI: $10.1051 / \mathrm{e} 3$ sconf $/ 20199106003$

19. N.F. Kashapov, M.M. Nafikov, M.Kh. Gazetdinov, S.M. Gazetdinov, A.R Nigmatzyanov, IOP Conf. Ser. Mat. Sci. and Engin., 412, 012038, (2018), DOI: $10.1088 / 1757-899 \mathrm{X} / 412 / 1 / 012038$ 